Title of manuscript: Post-crisis approaches to state intervention: new developmentalism or industrial policy as usual?

Author: Andrea Szalavetz

Affiliation: Centre for Economic and Regional Studies of the Hungarian Academy of Sciences

Address: 45, Budaörsi út, Budapest, Hungary, $\mathrm{H}-1112$

Phone: +36(30)84-88-068

Fax: + 36 (1) 309-2650

E-mail: szalavetz.andrea@krtk.mta.hu 


\title{
Post-crisis approaches to state intervention: new developmentalism or industrial policy as usual?
}

\begin{abstract}
:
The 2008 global crisis seems to have radically broken with the prevailing neoliberal ideology and practice concerning states' minimal involvement in the economy. This paper is an essay and a literature review on the post-crisis features of 'industrial policy'-type state interventions.

We investigate whether crisis-era interventions have given way to neoliberal governments' more explicit stance on industrial policy, once markets have more or less calmed down. We survey the changes that had taken place in the global context of state interventions by the time of the outbreak of the crisis, and argue that crisis did not provoke any 'return to the state'. It rather reinforced ongoing approaches to industrial policy, or has simply brought states' prevailing practices to the fore. Though post-crisis statemarket relations in established neoliberal advanced economies have become more similar to those of 'statist' contender states, policy convergence has been limited, since even the pre-crisis years have been characterised by non-negligible commonalities. These commonalities, i.e. neoliberal economies' (in particular the U.S.') substantial interventionism have been largely overlooked before the crisistriggered awakening interest in industrial policy.

The observed modest convergence has been bi-directional, driven by neoliberal states' inclination to devising formal strategies and conversely, by emerging economies' becoming more familiar with intervention practices allowed by international organisations. Common global challenges and increased global interconnectedness have also been powerful drivers of convergence.
\end{abstract}

Keywords: state intervention, industrial policy, STI policy, green industrial policy, WTO

JEL codes: L50, L52, F02, F13, O38

\section{Introduction and overview}

Following a turbulent period marked by massive state interventions to save the crisisridden global economy from financial collapse and depression, and manage the Eurozone crisis, tranquillising financial markets now allow for a cool-minded analysis of the role of the state in steering economic development.

The 2008 global crisis seems to have radically broken with the prevailing neoliberal ideology and practice concerning states' minimal involvement in the economy (Clift-Woll, 2012). Government responses to the crisis have gone far beyond containment-type monetary and fiscal measures and included egregious elements thought as died out for long, such as consumption stimulation, subsidy packages; stimulus programmes, bank nationalisation; and bailouts of underperforming private, financial and non-financial economic actors threatened by bankruptcy. Many of these measures showed remarkable resilience half a decade after the breakout of the crisis (Evenett, 2013a; 2013b).

Emergency measures were coupled with a marked ideological turn, as reflected among others by president Obama's call for the developmental revitalisation of the American industry (Kyung-Sup et al., 2012) or by cracks in the conviction of determined neoliberal international institutions, such as the IMF (calling for a global fiscal stimulus of 2 percent of GDP) or of the World Bank (launching the 'Competitive Industries \& Innovation Program' - Wade, 2012). The reconsideration of past ideological convictions was prompted also by the global expansion of some 'statist' 
economies (in particular China, Brazil and Russia) that were less affected by the global crisis.

Consequently, the years that followed the 2008 global crisis were described as post-neoliberal transformation in the global political economy (Schmalz-Ebenau, 2012). Analysts have been uniform in pointing to nation states' renewed commitment to steer economic development.

This essay investigates the post-crisis features of state interventions. More specifically, we will discuss interventions associated with industrial policy, i.e. interventions aimed at altering the structure of economic activity toward sectors, technologies or tasks that are expected to offer good prospects for national economic growth; improve local actors' competitiveness and enhance national economic performance and/or societal welfare (Warwick, 2013). Hence, we do not examine macroeconomic policy instruments such as interest rate or exchange rate manipulation, irrespective of their contingent potential to influence competitiveness.

We investigate whether crisis-era interventions have given way to advanced economy governments' (in particular to neoliberal governments') more explicit stance on industrial policy, even after markets have more or less calmed down. We survey the changes that had taken place in the global context of state interventions by the time of the outbreak of the crisis, and argue that crisis did not provoke any 'return to the state': it rather reinforced ongoing approaches to industrial policy, or has simply brought these attitudes to the fore.

The rest of this essay is structured in three sections. Section 2 is concerned with the changing global context of state interventions and analyses some lessons of crisis-era rescue measures. Section 3 discusses post-crisis approaches to and instruments of policy interventions. Section 4 provides some concluding remarks.

\section{The changing global context of state interventions}

By the time of the crisis-induced surge of state activism, major changes had taken place in the global context of state interventions. First and foremost, the decline in transportation, communication and coordination costs has accelerated a long ongoing process: the fragmentation and geographical dispersion of production. The global economy has become structured around global value chains (GVCs) (GereffiFernandez-Stark, 2011), which has made the concepts of 'domestic' or 'national' perceptively elusive (OECD, 2013a). The massive relocation of value adding activities to developing countries and in particular the consequent shrinkage of the manufacturing sectors in advanced economies provoked outcries for a 'manufacturing imperative' (reviewed by Stöllinger et al., 2013), i.e. for industrial policy interventions that enhance the competitiveness of manufacturing. Traditional advanced economies have been confronted also with the challenge of shifting end markets from the 'global North' to selected emerging economies (Cattaneo et al., 2010; Kaplinsky-Farooki, 2011) and with the global expansion of remarkably efficient contender states (van der Pijl, 2012), characterised by direct and systemic industrial policies.

The second major change concerns the transition of the dominant economic pattern from industrial to knowledge-based (Dobrinsky, 2009). Accordingly, ongoing shifts in the contribution of individual factor inputs to value creation have been reinforced, or, at least they have become obvious as a result of the transformed global organisation of value adding activities (production fragmentation and offshore outsourcing) on the one hand, and due to improved measurement methods (Corrado 
et al., 2009) on the other hand. Intangible capital was recognised as a key factor of growth. Similarly, the fact that the most important drivers of competitiveness are of an intangible character has become universally accepted (Garcia-Ayuso, 2003; Granstrand, 2000; Peneder, 2000; van Ark, et al. 2009).

The necessity to revisit both the intervention modalities and the efficiency of industrial policy was also underlined by the recognition that GVC-actors' value capture potential is closely associated with intangible activities (Dedrick et al., 2010; Mudambi, 2008; Shin et al., 2012). The rising importance of value capture over value creation is well-reflected by the surging scholarly and policy interest in the concept of the middle-income trap (Kharas and Kohli, 2011; World Bank, 2012).

Advanced economies are well-positioned to capture value - even at a time of the hollowing out of their manufacturing sectors - as reflected by the increasing value added to production ratio of their manufacturing firms - documented in UNIDO International Yearbooks of Industrial Statistics. Nevertheless, the fact that above and beyond manufacturing activities, relatively advanced, value added intensive tasks, in particular R\&D activities are also being increasingly offshored or outsourced to peripheral GVC-participants (Manning et al., 2008; Lewin et al., 2009), requires specific strategies that address the related issues.

Conversely, catching-up middle-income economies are confronting 'the Prebisch-Singer trap of the $21^{\text {st }}$ century'. This concept was advanced by MilbergWinkler (2013), who paraphrased the development trap expounded by the two classical development economics scholars (Prebisch, 1949; Singer, 1950). According to the Prebisch-Singer hypothesis, developing countries' (excessive) specialisation in and increasing supply of commodities and agriculture depresses their terms of trade and inhibits the structural adjustments (industrialisation) necessary to raise income and modernise. In the $21^{\text {st }}$ century, catching-up economies' export-oriented industrialisation confronts similar challenges. ${ }^{1}$ Though it has seemingly become relatively easy to industrialise simply by joining global value chains (Baldwin, 2014), the fact that every catching-up economy tries to follow the same export-oriented industrialisation strategy by plugging into global value chains at the bottom of the smile curve (Mudambi, 2008), equally depresses their terms of trade and prevents them from upgrading and raising income.

These new developments in the world economy, necessitating that states in advanced and catching-up economies alike, undertake increasingly complex tasks have been obvious already since the early 2000s, but they have come to the fore and questioned the prevailing neoliberal refusal of industrial policy only when the financial crisis hit the global economy.

Consequently, beyond the ad hoc fire fighting measures, the global crisis prompted governments to reconsider the principles of state intervention and be more inclined to devising coherent strategies that aim to enhance economic performance (Stiglitz et al., 2013).

Nevertheless, the interpretation of these developments as a post-crisis rebound of the activist, developmental state is mistaken: the role of the state has never - not even in the era of 'triumphant neoliberalism' - been confined to the provision of framework conditions (Weiss, 2012). State activism has never receded: it rather took different forms while continuously adapting to changing environment and new challenges.

\footnotetext{
${ }^{1}$ Interestingly, this claim is advanced just at the time when the downward secular trend of primary commodity prices seems to have broken, with a commodity price boom lasting already for more than a decade now.
} 
Consider the remark, advanced by Weiss (2012) in this respect. Weiss argues that advanced economy governments' current science, technology and innovation (STI) policy interventions have much in common with the traditional industrial policy approaches that targeted infant industries. Nowadays, "infant industries lie in the knowledge-intensive rather than in labour- or capital-intensive sectors [... and these industries] do not need old-style tariff protection or export subsidies, [...they rather need support in the form of] R\&D infrastructure, R\&D subsidies, and cost-shared partnerships; intellectual property licensing and protection; innovation-led procurement targeting new technologies; standard setting; and public sponsorship of venture capital funds." (ibid. pp. 30-31).

In Cimoli et al.'s (2009, p.26) wording, major developed countries have always featured relatively high degrees of intervention. "What primarily differentiates developed and developing countries are the instruments, the institutional arrangements and the philosophy of interventions."

Before elaborating on the post-crisis features of state interventions, some paragraphs will be dedicated to the lessons of the crisis-era emergency interventions that have been meticulously documented by international organizations (e.g. the WTO, OECD, UNCTAD, and the World Bank) and NGOs, e.g. the Global Trade Alert (GTA).

Given that nowadays there are hardly any economic policy measures that do not affect international trade, states' rescue actions have been interpreted as rising protectionism - despite the G20 leaders' much-publicised commitment to a standstill on erecting new distortions to global commerce in 2008 (Evenett, 2013a; 2013b; Evenett-Fritz, 2010; Evenett-Vines, 2012).

A key thesis of the literature on rising protectionism is that nowadays, most of the top offenders of the global free trade architecture resort to creative, hard-to-detect forms of protectionism that are subject to no or to weak WTO rules, including bailouts, stimulus packages, 'buy national provisions', public procurement, export taxes, etc. In fact, during and following the global crisis, it is not overall trade restrictiveness measured by traditional indicators that has risen, but rather murky protectionism (Kee at al., 2013). This claim is supported by the large gap between WTO's and GTA's perception of the evolution of trade restrictiveness ${ }^{2}$ (EvenettWermelinger, 2010).

The term 'murky' is an important finding of these papers in itself, since it suggests that various state initiatives (aimed to mitigate the devastating effects of the crisis; reignite growth and lower unemployment; improve competitiveness; mitigate climate change and encourage green growth; improve energy efficiency, etc.) have negative implications for foreign commercial interests without directly violating WTO obligations. Two conclusions derive from this recognition.

Firstly, the claim advanced by Wade (2003) on the constraints imposed by WTO membership on the ability of governments to engage in industrial policy ought to be revisited. In fact, WTO membership does not seem to radically constrain governments' developmental and protective interventions (Evenett, 2012).

Secondly, this recognition highlights the extent of interdependence of selected policy subsystems e.g. that of industrial policy, investment policy, fiscal policy with trade policy. It underscores that there is no such thing as an exclusively domestic economy-oriented policy.

\footnotetext{
${ }^{2}$ WTO is much more optimistic than GTA, claiming that the increase of protectionism is negligible.
} 
As a matter of fact, the most obvious examples of state intervention during the crisis era (subsidies, bailouts, stimulus programmes etc.) were seemingly domestic economy-oriented, and not directly related to trade. A recent argument that these two phenomena are the two sides of the same coin was advanced by Erixon-Sally (2010), advocating that having 'Keynes at home and Smith abroad' is practically impossible. According to proponents of this Janus-faced policy, "greater government macro- and microeconomic interventions are needed at home to stimulate recovery and preserve social stability - and thereby prevent a slide into protectionism. But this should proceed in tandem with open markets abroad" (Erixon-Sally, 2010: p. 8). However, more government intervention at home will necessarily generate protectionism at the border - as it happened in the managed trade era of the 1970s and 1980s.

Recent crisis management measures, in particular selected countries' 'green fiscal stimulus programmes' have substantiated this claim with new pieces of evidence. Consider for example the Clean Energy Package of the American Recovery and Reinvestment Act, which included more than $\$ 100$ billion investment to advance the development and deployment of renewable energy technologies. At the end of the day, Chinese producers were among the key beneficiaries of demandoriented incentives. For example in the case of solar panels, U.S. producers lost substantial part of their domestic market share, and many of them went bankrupt, because they could not stand the Chinese competition. These developments, for example, the much-discussed Solyndra case have become conspicuous examples of the misallocation of public funding. Solyndra, a U.S. solar panel manufacturer had benefited from huge loan guarantees, low-interest loans, tax reductions etc. before going bankrupt (Rodrik, 2013).

The dramatic expansion of Chinese solar panel export prompted the U.S. government (and similarly the EU) to impose tariffs and antidumping duties on solar panels imported from China (Karp-Stevenson, 2012).

A similar escalation of domestic subsidy provision to discrimination against foreign investors was documented by Aggarwal-Evenett (2012) in the wind power industry. Following the extension of production tax credits and the introduction of an installation tax credit (and various other incentives) enacted in the framework of the 2008 U.S. Emergency Economic Stabilization Act, and of the 2009 American Recovery and Reconstruction Act, it was soon discovered, that a large share of the radically increased financial assistance to the wind power industry has been captured by foreign manufacturers, which provoked significant political pressure for discrimination.

In summary the lessons of crisis interventions have provided empirical evidence to substantiate the theoretical claims about the elusive character of 'national' in a world economy structured around GVCs. This, together with other new global economic developments made the reconsideration of the philosophy of state interventions and the reconfiguration of the applied strategies indispensable. Nevertheless, as it will be shown in the subsequent section, approaches to industrial policy do not display radical changes.

\section{3. 'New' approaches to and new-old instruments of state intervention}

Regarding the extent and the depth of the changes in the philosophy of state interventions following the devastating years of the crisis and in the substantially transformed global environment Michalopoulos-Ng's (2013) words could be 
paraphrased. The referred authors argue for a more restrained interpretation of crisisera and post-crisis policy practice than what GTA's alarmist outcries about rising protectionism suggest. They claim that far less additional protection has been put in place following the 2008 financial crisis compared with what had been feared or what had happened in earlier crises. In a similar manner, the alleged new approaches (Naudé, 2010a, 2010b; Warwick, 2013) to state interventions are far less new that what has been expected: they are rather enhanced versions of past ideologies: no turn of the tide can be observed. The employed policy instruments are not really new either: at most, the traditional instruments are deployed differently.

Similarly to past approaches, the legitimacy of state interventions is recognised under specific conditions (Aghion et al., 2011), and these conditions do not seem to have become broader or more diversified than previously.

State interventions can be justified provided they address grand societal challenges, such as climate change (see e.g. Acemoglu et al. 2012), resource shortages, aging, health, urban development, information society, criminality and safety and the like (Edler et al., 2012), since these broad challenges require long-run, consistent, well-coordinated efforts and the threshold size of necessary investments is above the capacity of individual stakeholders.

Legitimate industrial policies are formulated in a broad, horizontal and systemic manner. Broadness refers to the scope of interventions: firm-level interventions, strongly related to the oft-used concept of 'picking winners' (or to the promotion of 'national champions') are excluded and even sector-level interventions (i.e. ones that target specific sectors) can rarely be justified. Subsidies and other incentives should be technology neutral to prevent lock-in and encourage competition.

State interventions have always been considered justified when applied to foster technological development (Block, 2008; Soete, 2007). Soete (ibid.) described the evolution of policy thinking in this respect. The first milestone of this evolution was the transformation of sectoral targeting from low to high-tech sectors, i.e. from a defensive support aimed at declining industries to an offensive one, addressing strategic sectors that feature increasing returns. In this way intervention target 'dynamic growth efficiency instead of static allocative efficiency'. The next milestone on the way of industrial policy's metamorphosis into innovation policy was a more systemic formulation of the policy rationale, with emphasis "away from the sectoral dimension towards the much broader national institutional framework [...] which appeared of crucial importance to the speed, extent and success by which innovations got introduced and diffused in the economy." (ibid. p. 278).

Authors emphasise that sectoral interventions need to be reconciled with competition policy principles (Aghion et al. 2012). Promotional programmes are considered effective if they are not directed to established firms, but formulated in a way to encourage entry and enhance thereby established firms' innovation activities. Subsidies are legal, if allocated through open competition, and if they are not concentrated on one single firm or industry, but rather decentralised and distributed over a larger number of firms/industries (Aghion et al., 2011; Buigues-Sekkat, 2011).

This lengthy enumeration makes analysts recall a catchphrase that characterises today's thinking about industrial policy: it is the 'how' rather than the 'why' of industrial policy that matters (Naudé, 2010a; Rodrik, 2009).

This lesson, namely that the formulation (the labelling) of objectives and of intervention instruments is what matters, has been systematically learned by emerging and advanced developmental economies: they have a good understanding 
of what practices are allowed. Consider for example Japan, where already pre-crisis industrial policy and its implementing institutions have been reorganised in a way to emphasise horizontal rather than sectoral objectives, such as 'industry reorganisation', 'human resources', 'new industries', and lately, 'sustainability' and 'renewable energy resources' (Nezu, 2007). For example, instead of targeting the Japanese automobile industry, interventions aim to foster 'next-generation transport solutions', 'new materials', 'frontier technologies' and the 'deployment of Japanese technologies and products in the world market' (O'Sullivan et al., 2013).

Or, consider the 'green fiscal stimulus programmes' of the crisis years, where in most cases the label of 'sustainability' was used as a pretext for the implementation of selective, targeted developmental programmes (Wermelinger, 2011). One example is that the temporary state aid granted to ailing automotive producers during the 2008-2009 crisis, and particularly the later support schemes, were increasingly formulated as 'green car initiatives'. Examples include the Green Vehicle Purchasing Promotion Measure in Japan (Kitano, 2013); the U.S. government's $\$ 3$ billion cash-for-clunkers programme (Copeland-Kahn, 2013). Indeed, green industrial policies comprise several instruments considered as taboo in most other contexts, such as direct subsidies, competition distorting regulations, purchase of outputs at above-market prices (for example in the framework of demonstration programmes), cost-based compensations for producers (feed-in tariffs to promote the generation of renewable energy-based power), concessional (belowmarket-interest-rate) loans, etc.

Aşıcı-Bünül (2012) analyse the catchword of 'Green New Deal' and contend that states have systematically given 'green colour' to their economic stabilisation, economic recovery and job creation programmes (e.g. in Korea, China or in the U.S.), though the green character of some of the targeted sectors or of the implemented Green New Deal programmes is rather dubious.

Regarded from another angle, analysts are of a consensus opinion that some countries' coherent, well-designed, multidimensional green growth strategies can be considered a source of competitive advantage and a driver and facilitator of industrial restructuring (see Mathews et al. (2011) for China; Capozza (2011) for Japan, and Mathews (2012) for Korea).

Science, technology and innovation (STI) is another field that opens up wide opportunities for entrepreneurial states' (Mazzucato, 2013) developmental activities. STI is the field where the boundaries between the universally accepted methods of strengthening the national innovation capacity and fostering knowledge-based growth, and the unaccepted intervention modalities are rather blurred. Analysing the mechanisms of STI policies in the U.S., Block (2008) highlights the systematic and developmental character of interventions instead of the alleged prevalence of competitive market arrangements (absence of the state). Although STI policy measures are referred to as 'targeted resourcing', 'opening windows', 'brokering' and 'facilitation' (Block, ibid.), in reality, STI-specific state interventions are developmental, albeit decentralised and distributed among a wide range of government departments, innovation agencies; national, regional and local development agencies and other organisations, such as national development banks, public science foundations, publicly co-financed venture capital organizations etc.. Hence, direct government funding is performed in a hidden, decentralised manner, which, as Block (2008) noted, makes developmental interventions less conspicuous than if they would be carried out by strong, centralised governments. This is why the 
label of 'hidden developmental network state' precisely describes the U.S. approach to state intervention.

As argued by Lazonick-Mazzucato (2013) STI is a primary example of policy interventions that socialise the risks of the private sector (the public sector bears the highest risks of funding innovation) while at the same time privatising the rewards.

However, as the example of the civilian aircraft industry demonstrates (surveyed by Shin-Li, 2013), global trading partners systematically monitor each others' R\&D subsidisation practices and legal disputes over R\&D subsidies are on the increase. Analysing WTO Panel decisions the referred authors conclude that governments should avoid making R\&D support policy programmes directly targeted towards near-market $R \& D$ projects with a high export potential. Moreover, policy makers should be careful to use terms such as 'export promotion', and refrain from devising measures that would explicitly benefit specific industries or firms.

It is by no surprise that an increasing share of STI-specific interventions are formulated so as to promote the universally accepted objective of inter-organisational collaboration, conform to the networked structure of today's innovative activities. ${ }^{3}$ State interventions bring technology suppliers and users together, embed private sector initiatives in governments' broad visions (Warwick, 2013) by developing publicprivate partnerships and 'crowding in' private investments. A diversified range of instruments implement the state's catalysing function, and pool and channel private resources for the implementation of specific missions, including publicly financed venture capital schemes; loan guarantee schemes; support to science and technology parks or to high-tech clusters.

Another example of exemplary formulation of policy objectives is the case of public procurement: an increasingly powerful instrument of state intervention aimed to enhance (among others) STI policy objectives. It seemingly pertains to the selective approaches to industrial policy, in which the state takes the responsibility of selecting among competing technologies and actors. Nevertheless, according to its phrasing, public procurement identifies and signals needs; demonstrates the usefulness of innovative solutions; facilitates stakeholders' collaboration and enhances thereby the diffusion of new technologies (Georghiou et al., 2014).

Conversely, if policy objectives and the related instruments deviate from the universally accepted formulation, as it happened for example in the case of the Chinese indigenous innovation policy or in its strategic standardisation policy, international pressure prevents interventions from being long lasting. Chinese practice of fostering indigenous innovation, ${ }^{4}$ in particular the issuing of catalogues of products featuring indigenous innovation that receive preferential treatment in government procurement processes, has prompted charges of protectionism by foreign partners (Boumil, 2011). Some of the most disputed elements of China's 'Indigenous Innovation' measures have been abolished. ${ }^{5}$

\footnotetext{
${ }^{3}$ The theoretical underpinning of the states' role in the STI area is reflected by the 'Triple Helix' concept (Leydesdorff-Etzkowitz, 1996; 1998; Etzkowitz, 2008). This model advocates the collaboration - through market and non-market arrangements - of three actors: firms, universities and the state.

${ }^{4}$ To be accredited as a product of indigenous innovation, the product has to be produced either by an enterprise that has both created and registered its IP in China, or by a Chinese enterprise that obtained the relevant Chinese IP rights or licenses. (Boumil, ibid. p. 763.)

${ }^{5}$ China's international trading partners have been less successful when fighting against China's 'alternative indigenous standards', that have indeed been used as a protectionist instrument: as a tool in commercial negotiations, aimed to lower the royalty rates to be paid to foreign intellectual property holders (Breznitz-Murphree, 2013). "In consumer electronics, licensing fees squeeze already thin
} 
On the other hand these disputed measures are still applied at provincial or local levels (ibid. p. 767). In fact, liberal approaches at the national level frequently go hand in hand with the devolution of specific selective and competition distorting policy actions to the sub-national level.

The most conspicuous example is China, where strong provincial and local governments have the authority to adopt regulations; set regional standards; impose (sometimes discriminatory) taxes; define their own pillar industries (Hearing, 2009); provide generous subsidies to local actors and to foreign investors; finance local projects; launch R\&D support programmes; and erect trade barriers (Feng et al., 2013; Lin-Milhaupt, 2013; Poncet 2005). However, this phenomenon is not uniquely Chinese. As described in MacNeil-Paterson (2012), U.S. states (and not the federal level) can be considered the site of green policy intervention: states implement subsidies, launch regulatory programmes, and impose standards (e.g. renewable portfolio standards differ across states).

The theoretical underpinning of this phenomenon was expounded by Brenner et al. (2010) who argued that in an era of decentralised policymaking, when decisionmaking authority is distributed among various levels of government, the nation state may not be the adequate unit of analysis of institutional systems. For example, neoliberal policies and regulatory practices might be not homogenous within individual national territories: sub-national regulatory landscapes might differ from the national ones, since policies are implemented in different forms and degrees across places, scales and territories.

In summary, the convergence between advanced economies' approaches to state interventions and those of their dirigiste competitors has been relatively limited. Convergence has been bi-directional, driven by neoliberal states' increased inclination to devising formal strategies and conversely by emerging economies' becoming more familiar with intervention practices allowed by international organisations. Common global challenges and increased global interconnectedness have also been powerful drivers of convergence. Moreover, advanced, emerging and catching-up countries systematically monitor their peers' successful practices in a number of industrial policy fields ,(n particular in STI and in green industrial policies, and they emulate each others' practices by setting up similar institutions, devising similar support programmes and imposing similar regulations. ${ }^{6}$

profit margins. Development of low-cost and potentially competitive standards for similar or identical technology niches pushes foreign standards alliances to lower royalty rates." (ibid. p. 2). China's practice to establish unique and mandatory standards can be modified only with the adoption of an international agreement on standardisation practices.

${ }^{6}$ Consider the widespread emulation of the U.S. entrepreneurial universities; the setting up of technology transfer offices, and of publicly financed venture capital organisations; science and technology parks, and institutes of technology. Example of similar regulations is the U.S. Bayh-Dole Act that granted the ownership right of intellectual property originating from publicly funded universitybased research to universities. Similar legislation was enacted in several advanced and emerging economies (see e.g. Gross (2013) for China; Nezu (2007) for Japan; Stephen (2010) for India).

As for green industrial policy, most countries employ the same - in some cases quite selective instruments, including among others public investment in infrastructure, and in green R\&D (thematic, mission-oriented research); direct subsidies granted for the absorption and use of green technologies; public procurement (e.g. green vehicles); publicly funded demonstration programmes; regulations (e.g. renewable portfolio standards, fuel efficiency standards, technological standards, sector-specific carbon emission reduction targets); environmental taxes, tax credits (e.g. for investments in energyefficiency); accelerated depreciation for green investments; targeted, low-cost financing (through green funds, development banks, targeted public venture capital initiatives); loan guarantees for green development initiatives; government-sponsored eco-industrial parks; trade restrictions, feed-in tariffs; preferential pricing, purchase obligations, or mandated energy reduction targets for specific firms. 
On the other hand, the claim that the post-crisis convergence of industrial policies has been limited refers to the fact that even the pre-crisis years have been characterised by non-negligible commonalities. These commonalities, i.e. neoliberal economies' (in particular the U.S.') substantial developmental interventions have been largely overlooked before the crisis-triggered awakening interest in industrial policy (Block, 2008; Mazzucato, 2013; Weiss, 2012).

The convergent practices and multiplying commonalities notwithstanding, the path dependence and the necessary customisation of industrial policies hinders an excessive homogenisation of the landscape of state interventionism. Given that "industrial policies are [...] time-specific and development stage-related" OECD (2013: p. 102), multiplying commonalities reflect common challenges and developmental states' successful catching-up performance.

\section{Concluding remarks}

Papers discussing the recent approaches to state intervention advance two recurring albeit contradictory remarks. On the one hand, 1) in the era of globally interconnected economies (OECD 2013a), with global value adding activities structured around GVCs; 2) exposed to global capital markets; 3) constrained by international agreements and by the 4) potential exit of multinational companies, which risks an exclusion from GVCs - states experience growing limits to national policies that aim at shaping growth, improving competitiveness and promoting job creation within national borders.

Conversely, the remark advanced by Bresser Pereira (2010, p.19), stating "Despite conventional wisdom, globalization and nation-states are phenomena that do not contradict each other but are rather part of a same universe, which is the universe of capitalism." - is unambiguously supported by the empirical evidence of state activism in advanced and emerging economies alike.

Expectations towards states keep increasing and, for sure, today's challenges cannot be met through old-fashioned policy instruments aiming at picking winners. States have to be innovative in finding efficient ways to intervene in the economy and comply with ever stricter rules of the game. It is by no surprise that cross-cutting areas requiring broad-based, multidimensional actions, such as science and technology, or green growth and sustainability have become the key targets of strategic interventions. These policy fields are showcasing the new trends of state interventions: they can propel qualitative growth and structural upgrading and, at the same time they offer ample scope for the twin-drivers of effective policy action: emulation and innovation.

\section{Acknowledgement}

The background of this essay is a report prepared in early 2014 for the European Commission, Directorate General Enterprise under the contract No. SI2.670621 (Study on State Intervention in the Economy by EU Competitors, coordinator: WIIW). Funding of the research is gratefully acknowledged. The author of this article prepared the literature review as a background document to the report. This essay is a reworked version of the literature review. The opinion expressed in this article is that of the author and the paper does not constitute an endorsement by the European Commission. 


\section{References}

Acemoglu, D., Aghion, P., Bursztyn, L., \& Hemous, D. (2012). The Environment and Directed Technical Change. American Economic Review, 102(1), 131-66.

Aggarwal, V.K., \& Evenett, S.J. (2012). Industrial policy choice during the crisis era. Oxford Review of Economic Policy, 28(2), 261-283.

Aghion, P., Boulanger, J., \& Cohen, E. (2011). Rethinking industrial policy. Bruegel Policy Brief, No. 4., Brussels: Bruegel

Aghion, P., Dewatripont, M., Du, L., Harrison, A., \& Legros, P. (2012). Industrial policy and competition. NBER Working Papers, No. 18048, National Bureau of Economic Research.

Aşıcı, A. A., \& Bünül, Z. (2012). Green New Deal: A Green Way out of the Crisis?. Environmental Policy and Governance, 22(5), 295-306.

Baldwin, R. (2014). Trade and industrialization after globalization's $2^{\text {nd }}$ unbundling: How building and joining a supply chain are different and why it matters. In: Feenstra, R.C., \& Taylor, A.M. (Eds.) Globalization in an Age of Crisis: Multilateral Economic Cooperation in the Twenty-First Century. Chicago, University of Chicago Press, forthcoming

Block, F. (2008). Swimming against the current: The rise of a hidden developmental state in the United States. Politics \& Society, 36(2), 169-206.

Boumil III, S. J. (2011). China's Indigenous Innovation Policies Under the TRIPS and GPA Agreements and Alternatives for Promoting Economic Growth. Chicago Journal of International Law, 12(2), 755-781.

Brenner, N., Peck, J., \& Theodore, N. (2010). Variegated neoliberalization: geographies, modalities, pathways. Global Networks, 10(2), 182-222.

Bresser Pereira, L.C. (2010). Globalization and competition: why some emergent countries succeed while others fall behind. New York: Cambridge University Press.

Breznitz, D., \& Murphree, M. (2013). The Rise of China in Technology Standards: New Norms in Old Institutions. Research report prepared on behalf of the U.S. China Economic and Security Review Commission. Available at: http://origin.www.uscc.gov/sites/default/files/Research/RiseofChinainTechnologyStan dards.pdf

Buigues, P.A., \& Sekkat, K. (2011). Public subsidies to business: an international comparison. Journal of Industry, Competition and Trade, 11(1), 1-24.

Capozza, I. (2011). Greening Growth in Japan. OECD Environment Working Papers, No. 28, Paris: OECD Publishing. http://dx.doi.org/10.1787/5kggc0rpw55l-en

Cattaneo, O., Gereffi, G., \& Staritz, C. (Eds.). (2010). Global value chains in a postcrisis world: a development perspective. Washington D.C.: The World Bank.

Cimoli, M., Dosi, G., Nelson, R., \& Stiglitz, J. E. (2009). Institutions and policies shaping industrial development: An introductory note. In: Cimoli, M., Dosi, G., \& Stiglitz, J. E. (Eds.) (2009). Industrial policy and development: The political economy of capabilities accumulation. New York: Oxford University Press, pp. 19-38.

Clift, B., \& Woll, C. (2012). Economic patriotism: reinventing control over open markets. Journal of European Public Policy, 19(3), 307-323. 
Copeland, A., \& Kahn, J. (2013). The production impact of "cash-for-clunkers": implications for stabilization policy. Economic Inquiry, 51(1), 288-303.

Corrado, C., Haltiwanger, J., \& Sichel, D. (Eds.). (2009). Measuring capital in the new economy. University of Chicago Press.

Dedrick, J., Kraemer, K.L., \& Linden, G. (2010). Who profits from innovation in global value chains?: a study of the iPod and notebook PCs. Industrial and Corporate Change, 19(1), 81-116.

Dobrinsky, R. (2009). The paradigm of knowledge-oriented industrial policy. Journal of Industry, Competition and Trade, 9(4), 273-305.

Edler, J., Georghiou, L., Blind, K., \& Uyarra, E. (2012). Evaluating the demand side: New challenges for evaluation. Research Evaluation, 21(1), 33-47.

Erixon, F., \& Sally, R. (2010). Trade, globalisation and emerging protectionism since the crisis. ECIPE Working Paper, No. 2., Brussels: European Centre for International Political Economy.

Etzkowitz, H. (2008). The Triple Helix: University-industry-government innovation in action. New York Routledge.

Evenett, S.J. (2012). Did the WTO Rules Restrain Protectionism During the Recent Systemic Crisis? In: Eichengreen, B., \& Park, B. (2012). The World Economy After the Global Crisis: A New Economic Order for the 21st Century. Singapore: World Scientific, pp. 29-76.

Evenett, S.J. (2013a). Protectionism's quiet return: The GTA's pre-G8 summit report. London: Global Trade Alert and CEPR. Available at: http://www.globaltradealert.org/analysis

Evenett, S.J. (2013b). What restraint? Five years of G20 Pledges on Trade. The $14^{\text {th }}$ GTA Report. London: Global Trade Alert and CEPR. Available at: http://www.globaltradealert.org/analysis

Evenett, S.J., \& Fritz, J. (2010). Jumbo' discriminatory measures and the trade coverage of crisis-era protectionism. in Evenett, S.J. (ed.): Unequal Compliance: The 6th GTA Report, London: CEPR, pp. 49-58.

Evenett, S.J., \& Vines, D. (2012). Crisis-era protectionism and the multilateral governance of trade: an assessment. Oxford Review of Economic Policy, 28(2), 195210.

Evenett, S.J., \& Wermelinger, M. (2010). A snapshot of current protectionism: How important are the murkier forms of trade discrimination? In: Mikic, M., \& Wermelinger, M. (eds.): Rising non-tariff protectionism and crisis recovery. Bangkok, Thailand: UN ESCAP, pp. 8-26.

Feng, X., Ljungwall, C., Guo, S., \& Wu, A. M. (2013). Fiscal Federalism: a refined theory and its application in the Chinese context. Journal of Contemporary China, 22(82), 573-593.

García-Ayuso, M. (2003). Intangibles: lessons from the past and a look into the future. Journal of Intellectual Capital, 4(4), 597-604.

Georghiou, L., Edler, J., Uyarra, E., \& Yeow, J. (2014). Policy instruments for public procurement of innovation: Choice, design and assessment. Technological 
Forecasting and Social Change, In press, http://dx.doi.org/10.1016/j.techfore.2013.09.018

Gereffi, G., \& Fernandez-Stark, K. (2011). Global value chain analysis: a primer. Center on Globalization, Governance \& Competitiveness, Durham, NC.

Granstrand, O. (2000). The shift towards intellectual capitalism-the role of infocom technologies. Research Policy, 29(9), 1061-1080.

Gross, C.M. (2013). The growth of China's technology transfer industry over the next decade: implications for global markets. Journal of Technology Transfer, 38(5), 716747.

Hearing (2009). China's Industrial Policy and its Impact on U.S. Companies, Workers and the American Economy. Hearing Before the U.S. - China Economic and Security Review Commission, March, 24, http://origin.www.uscc.gov/sites/defaultffiles/transcripts/3.24.09HearingTranscript.pdf

Kaplinsky, R., \& Farooki, M. (2011). What are the Implications for Global Value Chains when the Market Shifts from the North to the South?. International Journal of Technological Learning, Innovation and Development, 4(1), 13-38.

Karp, L., \& Stevenson, M. (2012). Green industrial policy: trade and theory. World Bank Policy Research Working Paper, No. 6238.

Kee, H. L., Neagu, C., \& Nicita, A. (2013). Is protectionism on the rise? Assessing national trade policies during the crisis of 2008. Review of Economics and Statistics, 95(1), 342-346.

Kharas, H., \& Kohli, H. (2011). What is the middle income trap, why do countries fall into it, and how can it be avoided? Global Journal of Emerging Market Economies, 3(3), 281-289.

Kitano, T. (2013). Disguised protectionism? Environmental policy in the Japanese car market. Mimeo, Available at: http://jsie2013spring.org/pub/F-3_paper.pdf

Kyung-Sup, C., Fine, B., \& Weiss, L. (2012). Introduction: Neoliberalism and Developmental Politics in Perspective. In: Kyung-Sup, C., Fine, B., \& Weiss, L. (Eds.): Developmental Politics in Transition: The Neoliberal Era and Beyond. London: Palgrave Macmillan, pp. 1-23.

Lazonick, W., \& Mazzucato, M. (2013). The risk-reward nexus in the innovationinequality relationship: who takes the risks? Who gets the rewards? Industrial and Corporate Change, 22(4), 1093-1128.

Lewin, A. Y., Massini, S., \& Peeters, C. (2009). Why are companies offshoring innovation? The emerging global race for talent. Journal of International Business Studies, 40(6), 901-925.

Leydesdorff, L., \& Etzkowitz, H. (1996). Emergence of a Triple Helix of universityindustry-government relations. Science and public policy, 23(5), 279-286.

Leydesdorff, L., \& Etzkowitz, H. (1998). The triple helix as a model for innovation studies. Science and public policy, 25(3), 195-203.

Lin, L.W., \& Milhaupt, C.J. (2013). We are the (national) champions: Understanding the mechanisms of state capitalism in China. Stanford Law Review, 65(4), 697-759. 
MacNeil, R., \& Paterson, M. (2012). Neoliberal climate policy: from market fetishism to the developmental state. Environmental Politics, 21(2), 230-247.

Manning, S., Massini, S., \& Lewin, A.Y. (2008). A dynamic perspective on nextgeneration offshoring: The global sourcing of science and engineering talent. The Academy of Management Perspectives, 22(3), 35-54.

Mathews, J.A. (2012). Green growth strategies - Korean initiatives. Futures, 44(8), 761-769.

Mathews, J.A., Tang, Y., \& Tan, H. (2011). China's move to a Circular Economy as a development strategy. Asian Business \& Management, 10(4), 463-484.

Mazzucato, M. (2013). The Entrepreneurial State: Debunking public vs. private sector myths. London and New York: Anthem Press.

Michalopoulos, C., \& Ng, F. (2013). Developing country trade policies and market access issues: 1990-2012. World Bank Policy Research Working Paper, No. 6463, Washington D.C.: The World Bank, Available at: $\underline{\mathrm{http}: / / \mathrm{www}-}$ wds.worldbank.org/external/default/WDSContentServer/IW3P/IB/2013/05/29/000158 349 20130529115204/Rendered/PDF/WPS6463.pdf

Milberg, W., \& Winkler, D. (2013). Outsourcing Economics. Global Value Chains in Capitalist Development. Cambridge: Cambridge University Press

Mudambi, R. (2008). Location, control and innovation in knowledge-intensive industries. Journal of Economic Geography, 8(5), 699-725.

Naudé, W. (2010a). Industrial policy: Old and new issues. World Institute for Development Economics Research Working Paper, No. 106.

Naudé, W. (2010b). New challenges for industrial policy. World Institute for Development Economics Research Working Paper, No. 107.

Nezu, R. (2007). Industrial policy in Japan. Journal of Industry, Competition and Trade, 7(3-4), 229-243.

OECD (2013). Perspectives on Global Development 2013: Industrial Policies in a Changing World. Paris: OECD Publishing. http://dx.doi.org/10.1787/persp glob dev2013-en

OECD (2013a). Interconnected Economies: Benefiting from Global Value Chains. Paris: OECD Publishing.

O’Sullivan, E., Andreoni, A., López-Gómez, C., \& Gregory, M. (2013). What is new in the new industrial policy? A manufacturing systems perspective. Oxford Review of Economic Policy, 29(2), 432-462.

Peneder, M. (2000). Intangible assets and the competitiveness of European industries. In: Buigues, P., Jacquemin, A., Marchipont, F. (Eds.). Competitiveness and the Value of Intangible Assets. Cheltenham, Edward Elgar, pp. 117-153.

Poncet, S. (2005). A fragmented China: measure and determinants of Chinese domestic market disintegration. Review of International Economics, 13(3), 409-430.

Prebisch, R. (1949). Economic Survey of Latin America 1948. New York: United Nations

Rodrik, D. (2009). Industrial policy: don't ask why, ask how. Middle East Development Journal, 1(1), 1-29. 
Rodrik, D. (2013). Green industrial policy. Mimeo. Available at: http://www.sss.ias.edu/faculty/rodrik/papers

Sass, M., \& Szalavetz, A. (2014). Crisis-related Changes in the Specialization of Advanced Economies in Global Value Chains. Competition \& Change, 18(1), 54-69.

Schmalz, S., \& Ebenau, M. (2012). After Neoliberalism? Brazil, India, and China in the Global Economic Crisis. Globalizations, 9(4), 487-501.

Shin, N., Kraemer, K. L., \& Dedrick, J. (2012). Value Capture in the Global Electronics Industry: Empirical Evidence for the "Smiling Curve" Concept. Industry and Innovation, 19(2), 89-107.

Shin, W., \& Lee, W. (2013). Legality of R\&D Subsidies and its Policy Framework Under the World Trading System: The Case of Civil Aircraft Disputes. STI Policy Review, 4(1), 27-53.

Singer, H. W. (1950). The distribution of gains between investing and borrowing countries. The American Economic Review, 40(2), 473-485.

Soete, L. (2007). From industrial to innovation policy. Journal of Industry, Competition and Trade, 7(3-4), 273-284.

Stephen, T. K. (2010). Asian Initiatives on Bayh-Dole, with Special Reference to India: How Do We Make it More Asian. Chicago-Kent Journal of Intellectual Property, 10, 44-64.

Stiglitz, J. E., Lin, J. Y., \& Monga, C. (2013). The rejuvenation of industrial policy. World Bank Policy Research Working Paper, No. 6628.

Stöllinger, R., Foster, N., Holzner, M., Landesmann, M., Pöschl, J., \& Stehrer, R. (2013). A 'manufacturing imperative'in the EU-Europe's position in global manufacturing and the role of industrial policy. WIIW Research Report, No. 391., Vienna: Vienna Institute for International Economic Studies.

van Ark, B., Hao, J. X., Corrado, C., \& Hulten, C. (2009). Measuring intangible capital and its contribution to economic growth in Europe. EIB papers, 14(1), 62-93.

van der Pijl, K. (2012). Is the East Still Red? The Contender State and Class Struggles in China. Globalizations, 9(4), 503-516.

Wade, R.H. (2003). What strategies are viable for developing countries today? The World Trade Organization and the shrinking of 'development space'. Review of International Political Economy, 10(4), 621-644.

Wade, R. H. (2012). Return of industrial policy? International Review of Applied Economics, 26(2), 223-239.

Warwick, K. (2013). Beyond Industrial Policy: Emerging Issues and New Trends. OECD Science, Technology and Industry Policy Papers, No. 2, OECD Publishing. http://dx.doi.org/10.1787/5k4869clw0xp-en

Weiss, L. (2012). The Myth of the Neoliberal State. In: Kyung-Sup, C., Fine, B., \& Weiss, L. (Eds.): Developmental Politics in Transition: The Neoliberal Era and Beyond. London: Palgrave Macmillan, pp. 27-42.

Wermelinger, M. (2011). Recent "green" policies-contested environmental benefits and import distortions. Available at: http://www1.unisg.ch/www/edis.nsf/SysLkpByldentifier/4131/\$FILE/dis4131.pdf 
World Bank (2012). China 2030: Building a Modern, Harmonious and Creative HighIncome Society. Washington: The World Bank 